\title{
Mother-child transmission of Chagas disease: could coinfection with human immunodeficiency virus increase the risk?
}

\author{
Transmissão materno-fetal da doença de Chagas: poderia a co-infecção com \\ vírus da imunodeficiência humana aumentar o risco?
}

\author{
Pablo Gustavo Scapellato ${ }^{1}$, Edgardo Gabriel Bottaro ${ }^{1}$ \\ and María Teresa Rodríguez-Brieschke ${ }^{1}$
}

\begin{abstract}
A study was conducted on all newborns from mothers with Chagas disease who were attended at Hospital Donación F. Santojanni between January 1, 2001, and August 31, 2007. Each child was investigated for the presence of Trypanosoma cruzi parasitemia through direct examination of blood under the microscope using the buffy coat method on three occasions during the first six months of life. Serological tests were then performed. Ninetyfour children born to mothers infected with Trypanosoma cruzi were attended over the study period. Three of these children were born to mothers coinfected with the human immunodeficiency virus. Vertical transmission of Chagas disease was diagnosed in 13 children, in all cases by identifying parasitemia. The overall Chagas disease transmission rate was 13.8\% (13/94). It was 100\% (3/3) among the children born to mothers with HIV infection and $10.9 \%(10 / 91)$ among children born to mothers without HIV [Difference $=0.89 ; \mathrm{CI}_{95}=0.82-0.95 ; \mathrm{p}=0.0021$. We concluded that coinfection with HIV could increase the risk of vertical transmission of Chagas disease.
\end{abstract}

Key-words: Chagas disease. Human immunodeficiency virus. Congenital infection. Trypanosoma cruzi.

\section{RESUMO}

Foi realizado um estudo com todos os recém nascidos de mães chagásicas atendidas no Hospital Donación F. Santojanni, no período de1 de janeiro de 2001 a 31 de agosto de 2007. Cada criança foi submetida a pesquisa de parasitemia por Trypanosoma cruzi através do exame microscópico direto do sangue pelo método buffy coat, em três oportunidades, nos primeiros seis meses de vida. Após, foram realizados exames sorológicos. Foram avaliadas 94 crianças nascidas de mães infectadas com Trypanosoma cruzi durante o período do estudo. Três destas crianças eram filhas de mães co-infectadas pelo vírus da imunodeficiência humana. A transmissão vertical de doença de Chagas foi diagnosticada em 13 crianças, todos os casos por identificação de parasitemia. A taxa de transmissão global de doença de Chagas foi de 13,8\% (13/94); 100\% (3/3) entre os recém nascidos de mães infectadas com HIV e de 10,9\% (10/91) entre as crianças nascidas de mães sem HIV [Diferenta=0,89; IC $_{95}=0,82-0,95 ; \mathrm{p}=0,0021$ ]. Concluímos que a co-infecção com HIV pode aumentar o risco de transmissão vertical de doença de Chagas.

Palavras-chaves: Doença de Chagas. Vírus da imunodeficiência humana. Infecção congênita. Trypanosoma cruzi.

Chagas disease is a major source of morbidity and mortality in Latin America. The World Health Organization (WHO) has estimated that 16 to 18 million people are currently infected with Trypanosoma cruzi and that nearly 300,000 patients become infected and 21,000 die each year (UNICEF, UNDP, World Bank, WHO Special Program for Research and Training in Tropical Diseases: Chagas disease; accessed at http://www.who.int/tdr/ diseases/chagas/diseaseinfo.htm).

Because of vector control efforts in several countries, transmission through insect bites is decreasing. Thus, vertical transmission has become more important today. In fact, it is

1. Servicio Infectología, Hospital Donación F. Santojanni, Buenos Aires, Argentina Address to: Dr. Pablo Gustavo Scapellato. Colón 742, Burzaco (1852), Argentina. Telefax: $54114630-5773$

e-mail: pscapel@intramed.net

Recebido para publicação em 03/11/2008

Aceito em 20/03/2009 estimated that in Argentina vertical cases are at least 10 times more frequent than are acute cases due to vector transmission ${ }^{3}$.

Overlapping of human immunodeficiency virus and Trypanosoma cruzi infection occurs not only in endemic areas but also in non-endemic areas of North America and Europe. Reactivation of Chagas disease in individuals with human immunodeficiency virus (HIV) and chronic Trypanosoma cruzi infection has been reported but no experiences of vertical transmission in such settings have yet been communicated.

We conducted a study in an area without the risk of Chagas disease transmission through vectors or transfusion, to see whether coinfection with the human immunodeficiency virus could affect vertical transmission of American trypanosomiasis.

\section{MATERIAL AND METHODS}

We conducted a study on all children born to mothers with Chagas disease who were attended at Hospital Donación F. Santojanni 
between January 1, 2001, and August 31, 2007. The mothers' serological status of Chagas disease was studied by means of indirect hemagglutination, enzyme-linked immunosorbent assay and latex agglutination. Positive test results from two methods were required for a diagnosis of Chagas disease in the mothers to be made. HIV status was assessed by means of the enzyme-linked immunosorbent assay; positive tests results were confirmed using Western blot.

Trypanosoma cruzi parasitemia was investigated in the children through direct examination of blood under the microscope using the buffy coat method on three occasions over the first six months of life. Serological tests were then performed.

Children were diagnosed as cases of vertically transmitted Chagas disease if they presented either parasitemia or two positive serological tests after six months of life.

\section{RESULTS}

Ninety-four children were born to mothers with chronic Trypanosoma cruzi infection over the study period. Three of these children were born to one mother presenting HIV coinfection. The remaining mothers tested negative for HIV.

Vertical Chagas disease transmission was diagnosed in 13 children. All of them were diagnosed through parasitemia.

All of the 81 children who were negative for parasitemia presented negative serological tests at the age of six months.

The overall Chagas disease transmission rate was $13.8 \%$ (13/94). It was $100 \%(3 / 3)$ among the children born to the mother with HIV infection and 10.9\% (10/91) among the children born to mothers without HIV [ difference $=0.89 ; \mathrm{CI}_{95}$ for difference $=0.82-0.95 ; \mathrm{p}=0.0021]$.

Symptoms of acute Chagas disease were present in $1 / 3$ children born to the mother with HIV and in $2 / 10$ children born to non-HIV mothers.

The prevalence of low birth weight among the Chagas disease children was $2 / 3$ among the children born to the mother with HIV and $2 / 10$ among the children born to mothers without a diagnosis of HIV [p $=\mathrm{ns}]$.

The prematurity rate at birth was $2 / 3$ among the children born to the HIV-positive mother and 3/10 among the children with Chagas disease born to HIV-negative mothers [p =ns].

Among the children born to HIV-negative mothers, eight of them were four pairs of siblings, and another three were siblings born to one mother. In only one case did one of the two siblings acquire Chagas disease while the other did not.

None of the children born to the mother with HIV acquired it.

\section{DISCUSSION}

Several authors have reported vertical Trypanosoma cruzi transmission rates ranging from $2 \%$ to $10.4 \%^{2}$. The factors associated with vertical Chagas disease transmission are not well understood.
Geographical issues (probably relating to the regional distribution of different strains of Trypanosoma cruzi) were considered. The rates of vertical Chagas disease transmission are higher in Argentina than in Brazil².

Prematurity and low birth weight could be important for determining the risk of vertical Chagas disease transmission ${ }^{234}$. We did not find any difference regarding either of these factors between the children with Chagas disease born to HIV-infected mothers and those born to mothers without HIV.

The strain of Trypanosoma cruzi could be an important factor in mother-to-child transmission of American trypanosomiasis. In a study conducted on mice, Andrade found that the placental infection rate was influenced by the strain of Trypanosoma cruzi ${ }^{1}$.

The three children born to an HIV-infected mother were siblings, and therefore we cannot dismiss the possibility that intrinsic maternal factors could be involved. In an epidemiological study, Sánchez-Negrete $e t a l^{4}$ found that siblings of an infant infected with Trypanosoma cruzi were at high risk of infection themselves ${ }^{4}$. We could not clarify this point because of the small size of our sample, but the only sibling of a child with Chagas disease born to a mother without HIV infection in our sample did not acquire Chagas disease.

The level of parasitemia could be a major factor determining the risk of mother-to-child transmission. Storino et al reported a vertical transmission rate of $71 \%$ in rare cases of acute maternal Chagas disease $^{2}$, i.e. much higher than the rates of $5 \%$ to $10 \%$ communicated in cases of chronic maternal trypanosomiasis.

The level of parasitemia was higher in the individuals coinfected with HIV. In a study conducted by Sartori, Trypanosoma cruzi parasitemia was detected significantly more frequently in HIV-positive than in HIV-negative subjects, and HIV-infected patients also had higher levels of parasitemia 5 .

We think that high levels of parasitemia, as found in HIVinfected patients, could favor higher rates of vertical transmission of Chagas disease, as seen among children born to mothers with acute American trypanosomiasis.

Even if Chagas disease transmission via breastfeeding can be disregarded, this is an exceptional means of infection ${ }^{6}$. The children born to the HIV-infected mother were not breastfed.

This was a small and retrospective report, but we think it provides an initial piece in the puzzle of elucidating the interactions between the human immunodeficiency virus and Trypanosoma cruzi within the setting of vertical transmission of Chagas disease.

\section{REFERENCES}

1. Andrade SG. The influence of the strain of Trypanosoma cruzi in placental infection in mice. Transactions of the Royal Society of Tropical Medicine and Hygiene 76:123-128, 1982.

2. Freilij H, Altcheh J, Storino R. Chagas congénito. In: Storino R, Milei J (eds) Enfermedad de Chagas, Mosby-Doyma Argentina, Buenos Aires, p.267-278, 1994. 
3. Gürtler RE, Segura EL, Cohen JE. Congenital transmission of Trypanosoma cruzi infection in Argentina. Emerging Infectious Diseases 35:29-35, 2003.

4. Sánchez-Negrette 0, Mora MC, Basombrio MA. High prevalence of congenital Trypanosoma cruzi infection and family clustering in Salta, Argentina. Pediatrics 115:668-672, 2005

5. Sartori AMC, Eluf Neto J, Nuñes EV, Braz LMA, Caiaffa-Filho HH, Oliveira Jr OC, Amato Neto V, Shikanai-Yasuda MA. Trypanosoma cruzi parasitemia in chronic
Chagas disease: comparison between Human Immunodeficiency Virus (HIV) positive and HIV-negative patients. Journal of Infectious Diseases 186: 872-875, 2002.

6. Storino R, Jörg M. Vías de Infección y Aspectos Clínicos. In: Storino R, Milei J (eds) Enfermedad de Chagas, Mosby-Doyma Argentina, Buenos Aires, p. 185-207, 1994. 